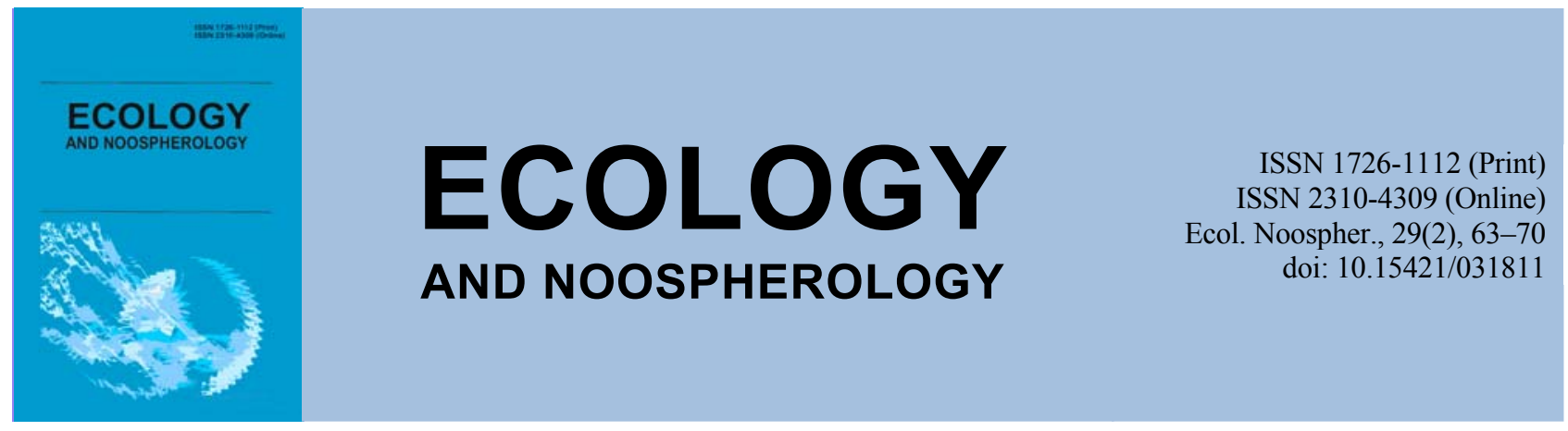

\title{
Perculiarities of introduction of Araliaceae Juss. in botanical gardens (Kyiv, Ukraine)
}

\author{
A. P. Morozko*, O. Y. Leshchenko*, O. V. Kolesnichenko*, Y. V. Lykholat**, M. Ziemianska***, \\ D. I. Bidolakh****, O. N. Tsarenko*****
}

\begin{abstract}
*National University of Life and Environmental Sciences of Ukraine, Kyiv, Ukraine
**Oles Honchar Dnipro National University, Dnipro, Ukraine

***Wroclaw University of Environmental and Life Sciences, Wroclaw, Poland

****Separated Subdivision of National University of Life and Environmental Sciences of Ukraine «Berezhany Agrotechnical Institute», Berezhany, Ukraine

*****M. G. Kholodny Institute of Botany of National Academy of Science of Ukraine, Kyiv, Ukraine
\end{abstract}

Article info

Received 12.10.2018

Received in revised form 20.10.2018

Accepted 26.10.2018

National University of Life and Environmental Sciences of

Ukraine, Rodimtsev General st., 19,

Kyiv, 03041, Ukraine.

Tel.: (044) 527-85-47

E-mail:

anasteziya.morozko@gmail.com

Oles Honchar Dnipro National University, Gagarin Ave., 72 Dnipro, 49010, Ukraine.

Wroclaw University of Environmental and Life Sciences, C. K. Norwida st., 25 , Wroclaw, 50-375, Poland.

Separated Subdivision of National University of Life and Environmental Sciences of Ukraine «Berezhany Agrotechnical Institute», Academic st., 20, Berezhany, 47501, Ukraine.

M.G. Kholodny Institute of Botany, NAS of Ukraine, 2, Tereshchenkivska St., Kyiv, 01004, Ukraine.
Morozko, A. P., Leshchenko, O. Y., Kolesnichenko, O. V., Lykholat, Y. V., Zemnianska, M., Bidolakh, D. I., \& Tsarenko, O. N. (2018). Perculiarities of introduction of Araliaceae Juss. in botanical gardens (Kyiv, Ukraine). Ecology and Noospherology, 29(2), 63-70. doi:10.15421/031811

The results of physiological, morphological, anatomical peculiarities of introduced plants of Araliaceae Juss. have been given. Study of seasonal growth and development peculiarities of Araliaceae Juss. showed that most of these plants were introduced successfully but the process was complicated by climatic conditions of the area in city Kiev. According to a comprehensive assessment a large number of studied species were highly evaluated for decorative effect. Introduced species of family Araliaceae Juss. are characterized by high-level adaptation to local soil and climatic conditions in Botanical gardens of Kiev. The vast majority of them bloom but not all can form seeds. Thus, among the introduced plants only five representatives of genus Acanthopanax Acanthopanax lasiogyne, Acanthopanax divaricatus, Acanthopanax sieboldianus, Acanthopanax trifoliatus and Acanthopanax wardii have high level of adaptation. To determine the prospect of cultivating research species we assessed the degree of winter resistance by the 5-point M. K. Vechova scale on the basis of visual observations in conditions of the open ground. The level of adaptation of plants was evaluated in the city Kyiv using the estimation scale measured in points and in percentages. Results of researches showed that the species have a high resistance to the effects of adverse factors. All types of this family are promising for introduction into culture and can be widely used in various branches of the national economy. A comprehensive assessment of the decorative effect of ornamental plant species was carried out by the O. G. Horoshyh and O. V. Horoshyh scales, according to which the decorative effect of the vast majority of studied species was highly appreciated. The results of our study shows that the introduced species of Araliaceae Juss. have a good prospect for further their use in ornamental gardening, urban greening and landscape design in private territories of citizens.

Keywords: adaptive index; adaptation success; decorative effect; reproductive ability; winter resistance

\section{Introduction}

Recently technogenic impact and climate change affect the state of living organisms: plants (Lykholat \& Hryhoryuk, 2005; Khromykh et al., 2018; Prisedsky et al., 2017), animals and people (Peregrym et al., 2014). In these conditions, introduction of introduced species into landscaping enhances the range of local spectrum of species having transformative environment properties (Alexeyeva et al., 2016).

In Ukraine, as well as throughout the world centers of plant protection and introduction are botanical gardens constantly increasing their diversity (Afanasyeva et al., 1997; Kilpatrick, 2014; Shalimov, 2008). Despite such a positive dynamics in the increased species diversity, it should be noted the introduction of rare plant species, as well as the introduction into the culture of any other group of plants, always occurs with losses associated with different objective and subjective reasons (Fedorov, 1982; Frei et al., 2014; Fujimaki et al., 2012; Heylighen, 2007), which is reflected on their external functional state (Karapetyan, Bukhov, 1986; Vorobyev, 1986; Endress, 2002). 
Therefore, during the introduction process for the further effective development of the collection of rare and introduced species of plants, more attention should be paid to the biomorphological, geographic and cenotic analysis of the studied species currently represented in collections of botanical gardens, in order to identify the most promising groups for further active use in landscaping on the basis of their features (Sokolov, 1957; Peregrym et al., 2014; Umair et al., 2017; Zaman et al., 2018; Zhang et al., 2018).

A large number of species originating from the Far East introduced in Ukraine. This is due to the fact that most of them have medicinal traits. The attention to oriental medicine causes by constant interest in the study of characteristics and therapeutic properties of these plants.

From this perspective, representatives of Araliaceae Juss. are of considerable interest (Eyde, Tseng, 1971; Davydov, Krikorian, 2000; Shang, Lowry, 2007), so the purpose of our research was the study of their introduction process in Kyiv' botanical gardens.

\section{Materials and methods}

Investigated species grow in collecting plantations within the city of Kyiv. Researched area includes Botanical Gardens of the city M. M. Gryshko National Botanical Garden of National Academy of Science of Ukraine (M. M. Gryshko NBG), A.V. Fomin Botanical Garden of Kyiv National T. Shevchenko University (A.V. Fomin BG), Botanical Garden of National University of Life and Environmental Sciences of Ukraine (BG of NULES) (Fig.1).

The climate of Kiev is moderately continental. The average annual temperature of ground air is $7.3^{\circ} \mathrm{C}$ with an age range of 5.1 to $9.7^{\circ} \mathrm{C}$. The average minimum air temperature reaches $-3.6^{\circ} \mathrm{C}$ and the absolute is $32.2^{\circ} \mathrm{C}$; average maximum $+11.6^{\circ} \mathrm{C}$, absolute $+39.4^{\circ} \mathrm{C}$. The sum of the average daily air temperatures higher than $+5{ }^{\circ} \mathrm{C}$ and equals $3020^{\circ} \mathrm{C}$, above $+10^{\circ} \mathrm{C}$ and equals $2695^{\circ} \mathrm{C}$. The meteorological period of vegetation continues averagely 207 days (Fig. 2).

The data of the average monthly temperature was used from the web-site of Central Geophysical Observatory of B. I. Sreznevsky [http://www.cgo.kiev.ua/]. The change in the minimum average annual temperature prevails over the maximum.

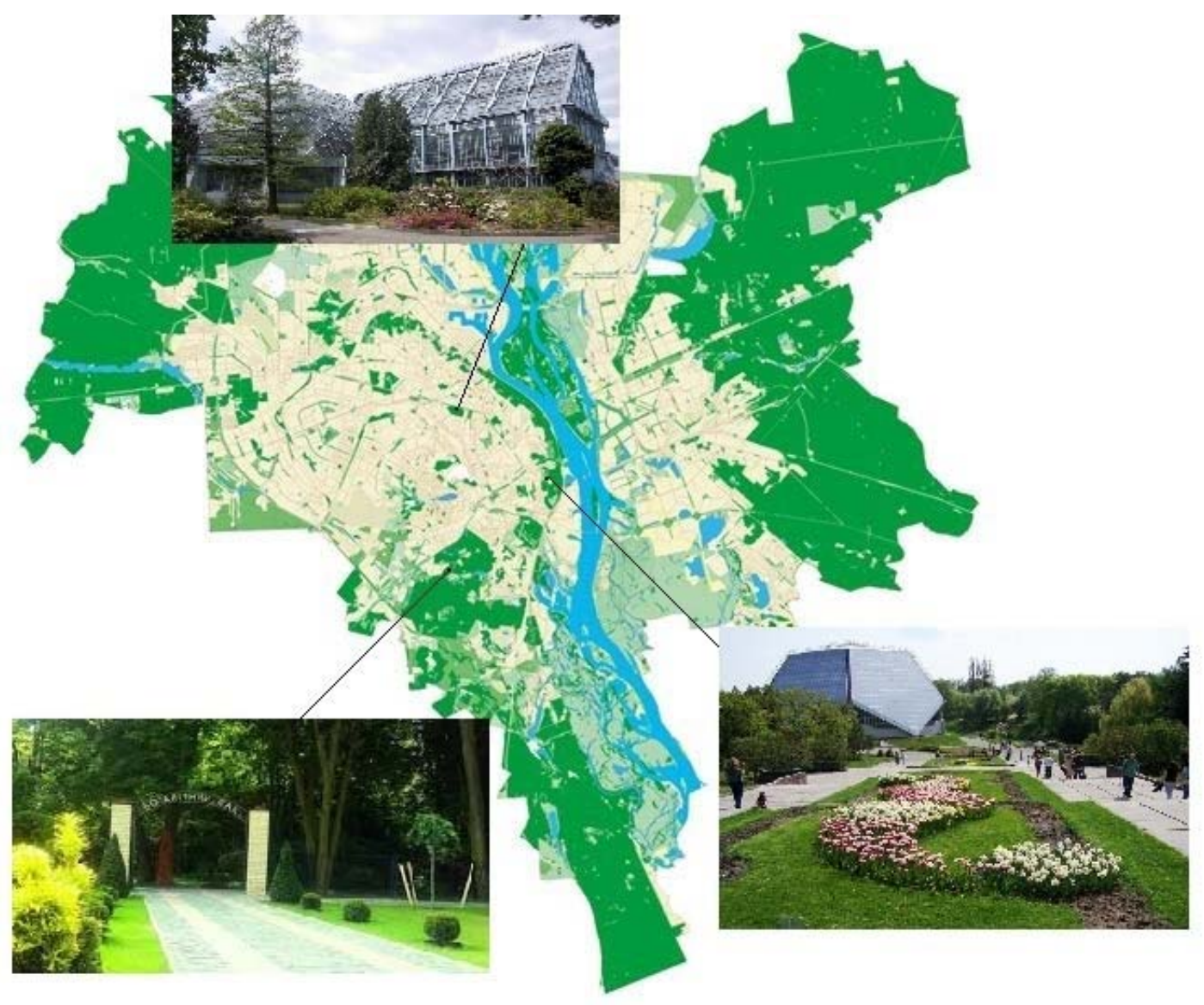

Fig. 1. Location of Botanical gardens on the territory of Kiev:

1 - A. V. Fomin Botanical Garden of Kyiv National T. Shevchenko University;

2 - M. M. Gryshko National Botanical Garden of National Academy of Science of Ukraine;

3 - Botanical Garden of National University of Life and Environmental Sciences of Ukraine

In the changing climate of Kiev, there are trends that suggest that over the past 20 years the average temperature in January and February has increased by almost 2.5 degrees. On a global scale, the number of cold days and nights has decreased and the number of warm days and nights has increased.

Winter period characterizes by alternation of frost with thaws. In average during the winter there are 8-10 thaws lasting from 5 to 30 days. Sometimes they can cause premature vegetation of plants. The duration of growing season is 190 205 days. The average annual amount of precipitation is 550 $700 \mathrm{~mm}$, the evaporation does not exceed $400-450 \mathrm{~mm}$.
The average rainfall is $655,3 \mathrm{~mm} /$ year with fluctuations ranging from 594.7 to $732.4 \mathrm{~mm} /$ year. Considering on difficult complex of terrain and significant general slope of the territory the precipitation for plants is ineffective. In average, there are about 100 days with snow cover in height from 10 to $30 \mathrm{~cm}$ (max. $75 \mathrm{~cm}$ ) in Kiev. During long thaws the snow cover disappears. It should be noted, that in some years there are significant fluctuations in the distribution of precipitation in months and in their total amount for the year.

The main soil-forming material is loess which locates on a depth of $130-170 \mathrm{~cm}$. The mechanical composition is medium loam. The loess is pale yellow in color, loamy, well sorted 


\section{Average monthly air temperature in Kiev, ser}

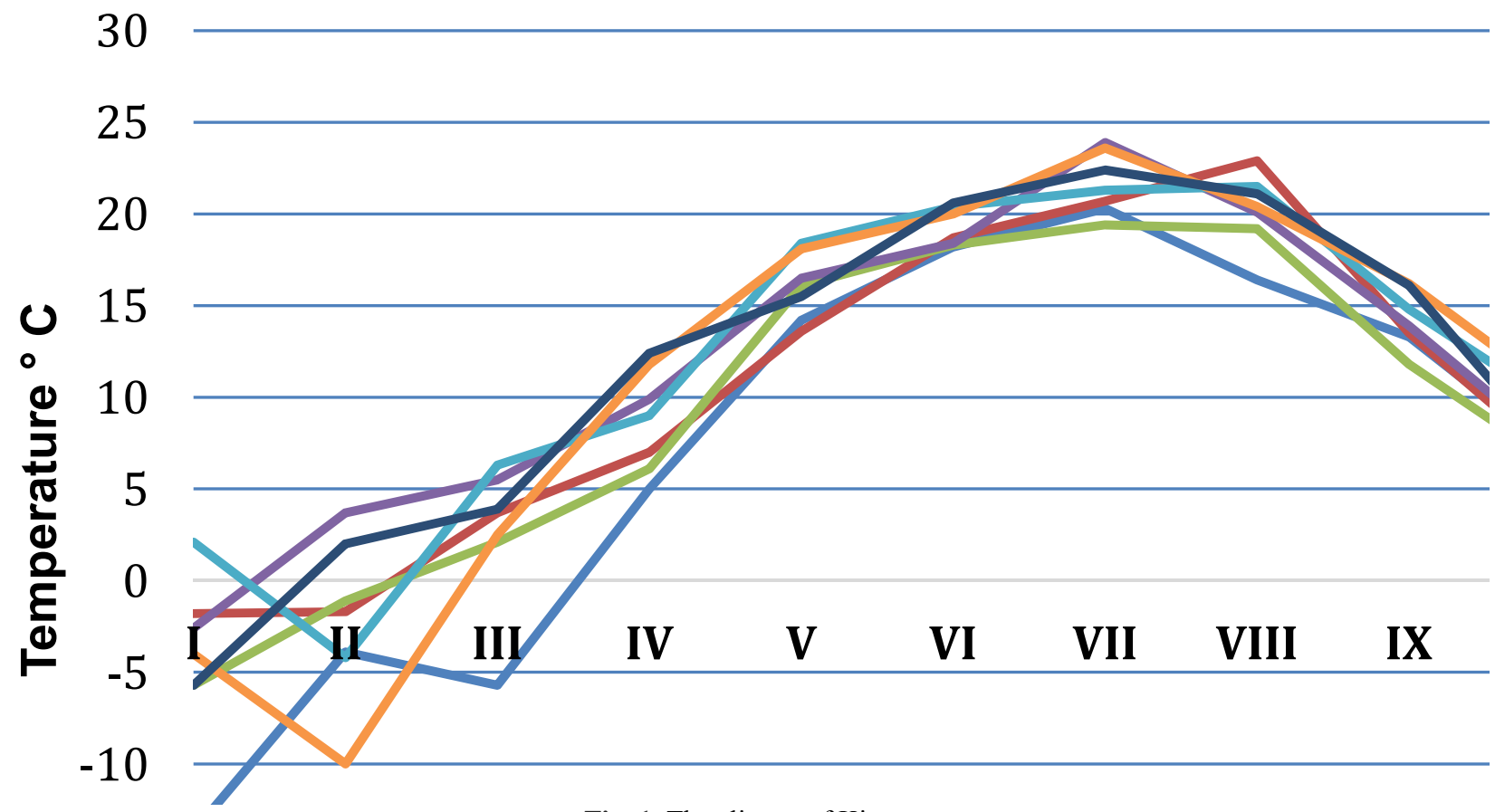

Fig. 1. The climate of Kiev

class of rockiness with developed porosity and lack of lamination. Carbonation is a characteristic feature of loess. Podzolized chernozem was formed on the base of loess.

In the stand of trees dominate such species as European hornbeams (Carpinus betulus L.) and English oak (Quercus robur L.). Grow such species as English field maple (Acer compestre L.) and Norway maple (Acer platanoides L.), smallleaved lime (Tilia cordata Mill) and European ash (Fraxinus excelsior L.). On the territory of botanical gardens growth oldaged oaks over 200 years old.

In the grass cover in the summer dominant herbaceous plant is Impatiens parviflora DC. Among other herbaceous species prevail Carex capillaris L., Aegopodium podagraria L., Asarum europaeum L., Galeobdolon luteum Huds., Stellaria holostea L., Viola odorata L., Polygonatum multiflorum (L.) All., Galium odoratuм (L.) Scop.

In spring there are several types of ephemeroids - plants that vegetate, bloom and yield only in the spring months and later dry up. They represented by Anemone ranunculoides L., Ficaria verna L., Corydalis cava (L.) Schweigg. \& Körte., C. solida (L.) Clairv., C. intermedia (L.) Merat, Gagea lutea (L.) Ker-Gawl. and G. minima (L.) Ker Gawl., Cardamine quinquefolia (M.Bieb.) Schmalh., Dentaria bulbiferia L. and Scilla bifolia L.

Plant observations were conducted on the territory of Botanical gardens of Kiev from August 2011 to September 2014. The age of trees was determined according to the materials of the last inventory. Height was set by using of the altimeter. Decorative qualities of species were estimated by 5-point scale of O. A. Kalinichenko (Table 1).

Comprehensive evaluation of decorative effect of decorative species of plants was conducted according to the scale of O. G. Horoshyh and O. V. Horoshyh (Kohno, Kurdiuk, 1994) (Table 2).

For determining the prospect of cultivating researched species we assessed the degree of resistance to winter conditions by 5 point scale N. K. Vehov (O. O. Kalinichenko, 1991) on the basis of visual observations in open ground (Table 3).
Table 1

Scale for assessing of decorative effect (O. O. Kalinichenko, 1991)

\begin{tabular}{cll}
\hline Points & $\begin{array}{c}\text { Decorative } \\
\text { effect }\end{array}$ & \multicolumn{1}{c}{ Features } \\
\hline 1 & Negative & $\begin{array}{l}\text { External appearance of plants } \\
\text { reduces their overall decorative } \\
\text { effect. }\end{array}$ \\
\hline 2 & Zero & $\begin{array}{l}\text { Decorative qualities are } \\
\text { imperceptible, plants have not } \\
\text { expressiveness on the general } \\
\text { background of plantings. }\end{array}$ \\
\hline 3 & Inconspicuous are \\
& Sufficient & $\begin{array}{l}\text { Decorative qualities aticeable, but indistinct and do } \\
\text { not increase the decorative } \\
\text { effect of plants. }\end{array}$ \\
\hline 4 & $\begin{array}{l}\text { Decorative qualities are } \\
\text { distinct, plants how up well on } \\
\text { the general background of } \\
\text { plantings. }\end{array}$ \\
\hline 0 & High & $\begin{array}{l}\text { Decorative qualities give the } \\
\text { plants a great attractiveness, } \\
\text { causing an observer a great } \\
\text { emotional feeling, admiration. }\end{array}$ \\
\hline
\end{tabular}

Table 2

Scale for comprehensive assessing of decorative effect

\begin{tabular}{ll}
\hline Points & Decorative effect \\
\hline To 14 & Low \\
$15-28$ & Medium \\
$29-42$ & High \\
\hline
\end{tabular}

Scale for assessing decorative attributes for O. G. Good and O. V. Good ones. 
Table 3

Scale for assessing of winter-resistance

\begin{tabular}{cl}
\hline Points & \multicolumn{1}{c}{ Visual characteristics } \\
\hline 0 & complete freezing and destruction of plants \\
\hline 1 & $\begin{array}{l}\text { terminal leader is completely damaged, but the } \\
\text { plant lives and continues to grow from the } \\
\text { lateral branches or can renewed from sprouts }\end{array}$ \\
\hline 2 & half of length of the terminal leader is damaged \\
\hline 3 & $\begin{array}{l}\text { the damage does not cover more than a quarter } \\
(1 / 4) \text { of length of the terminal leader }\end{array}$ \\
\hline 4 & $\begin{array}{l}\text { no damage of the terminal leader, a new sprout } \\
\text { develops from the apical bud }\end{array}$ \\
\hline
\end{tabular}

The degree of drought resistance was determined by the 6point scale of S. S. Pyatnitskiy (Kolesnichenko et al., 2010) (Table 4).

Table 4

Scale for assessing of drought-resistance

\begin{tabular}{cl}
\hline Points & \multicolumn{1}{c}{ Visual characteristics } \\
\hline 0 & Plant dies under drought \\
\hline 1 & $\begin{array}{l}\text { Leaves dropped off and dry off on the } \\
\text { shoots }\end{array}$ \\
\hline 2 & $\begin{array}{l}\text { More than half of leaves on plant and } \\
\text { part of shoots dry off }\end{array}$ \\
\hline 3 & Less than half of the leaves dry off \\
\hline 4 & $\begin{array}{l}\text { In the afternoon the leaves lose turgor, } \\
\text { but after night it is restored }\end{array}$ \\
\hline 5 & Plant does not suffer from drought \\
\hline
\end{tabular}

Adaptation success researched species was determined by methodology of O. O. Kalinichenko which took into account reproductive capacity, winter and drought tolerance. The level of adaptation was established by score scale in points and percentages $(\%)$ (Table 5).

\section{Table 5}

Scale for assessing of adaptation success of species (Adaptive index, O.O. Kalinichenko, 1991)

\begin{tabular}{cc}
\hline $\begin{array}{c}\text { Level of adaptation, } \\
\text { points }\end{array}$ & Adaptive rate amplitude, $\%$ \\
\hline Not adapted (0) & 0 \\
Low (I) & $1-25$ \\
Medium (II) & $26-50$ \\
Good (III) & $51-75$ \\
High (IV) & $76-100$ \\
\hline
\end{tabular}

\section{Results and discussion}

Representatives of family Araliaceae Juss. are shrubs, trees and vines. They attract attention to flowers during the flowering period, the shape and color of leaves. Assessment of the decorative nature of the studied species, presented in Table 6 .

During the visual assessment of the decorative items we took into account the architectonics of the body, wreaths, leaves, flowers and fruits. The results of the assessment of the decorative effect of Araliaceae Juss tree species on the basis of visual observations are given in Table 7.

During the observations of Araliaceae Juss. representatives in the beginning of vegetation we found damages from frost on branches of some species - Aralia mandshurica on the territory of the BG of NULES and on the territory of the O. V. Fomin BG (Fig. 2,3). At the same time 3 affected shoots were detected in one plant. We can conclude that degree of winter resistance of these species according to the 5-point scale M. K. Vehova is 3 points.
Table 6

Results of assessment of decorative effect of plants Araliaceae Juss.

\begin{tabular}{|c|c|c|c|c|c|}
\hline \multirow{2}{*}{ Specie } & \multicolumn{5}{|c|}{ Points } \\
\hline & 1 & 2 & 3 & 4 & 5 \\
\hline Acanthopanax lasiogyne & & & & + & \\
\hline Acanthopanax sessiliflorum & & & & & + \\
\hline Acanthopanax divaricatus & & & & & + \\
\hline Acanthopanax sieboldianus & & & & & + \\
\hline Acanthopanax trifoliatus & & & & & + \\
\hline Acanthopanax wardii & & & & & + \\
\hline Aralia cordata & & & & & + \\
\hline Aralia mandshurica & & & & & + \\
\hline Hedera cjlchica & & & & & + \\
\hline Hedera helix & & & + & & \\
\hline Eleutherococcus senticosus & & & & & + \\
\hline Kalopanax septemlobus & & & & & + \\
\hline
\end{tabular}

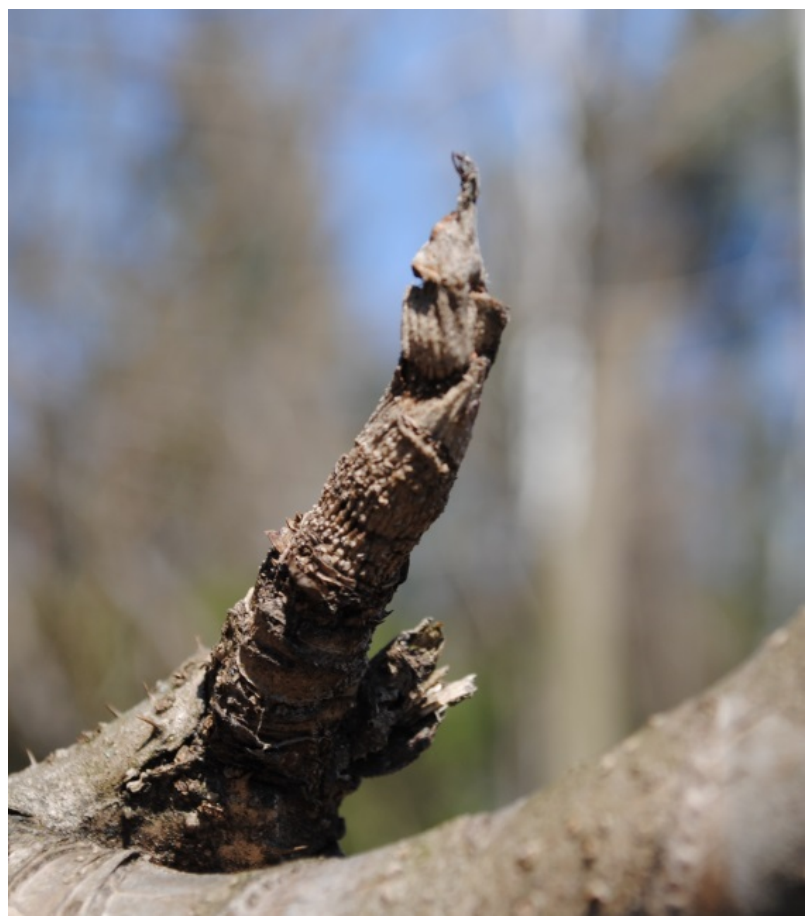

Fig. 2. Freeze-damaged branch of Aralia mandshurica

Another case of branch frost-demage was fixed in Eleutherococcus senticosus on the territory of the M. M. Gryshko NBG (Fig. 4).

The widest variety of woody species of family Araliaceae Juss. presented on the territory of the M. M. Gryshko NBG and A. V. Fomin BG. There are 9 species of plants of investigated family grow in open soil (Table 8).

According to the results of research was fixed the level of adaptation of species Araliaceae Juss. under conditions of the National Botanical Garden of the M. M. Gryshko NBG. Consequently, it weren't found representatives of the family Araliaceae Juss. which adapted weakly or not adapted at all (adaptive index is not lower than $36 \%$ ). Established that characterized by the highest rate of adaptation and ability of reproduction, so this specie of plant under conditions of city Kiev has first place by adaptation index.

The results of the studies indicate that Aralia mandshurica and Eleutherococcus senticosus more successful adapted under conditions of the BG of NULES compared with other species $(80 \%)$. However, plants of Hedera helix adapted weakly and the adaptive index is only $20 \%$ (Table 9). In general, this specie is characterized by a low level of adaptation on the territory of Kiev - does not bloom and therefore does not form fruit (not capable to generative reproduction). 


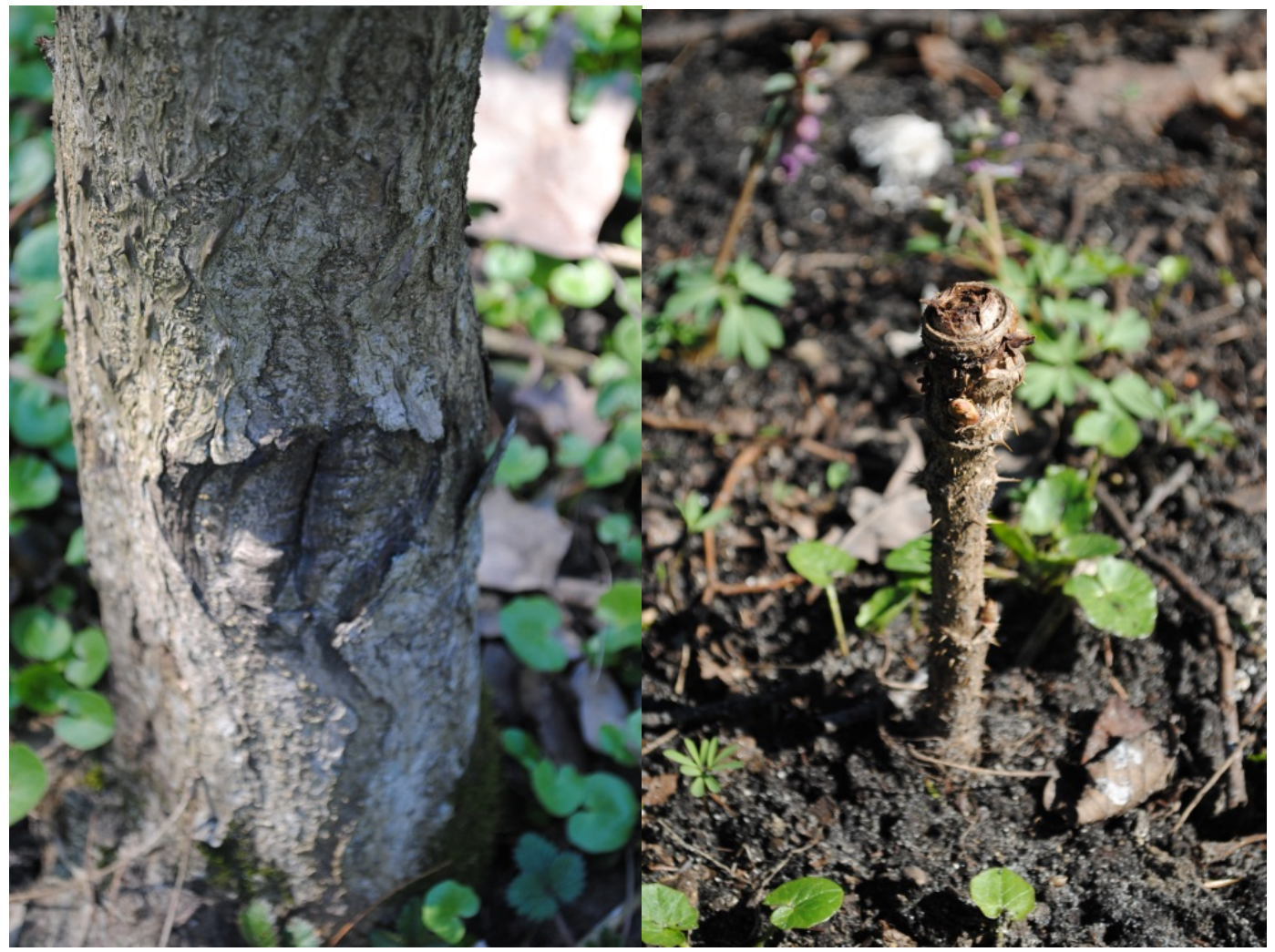

Fig. 3. Frost cleft and brunch freezing of Aralia mandshurica

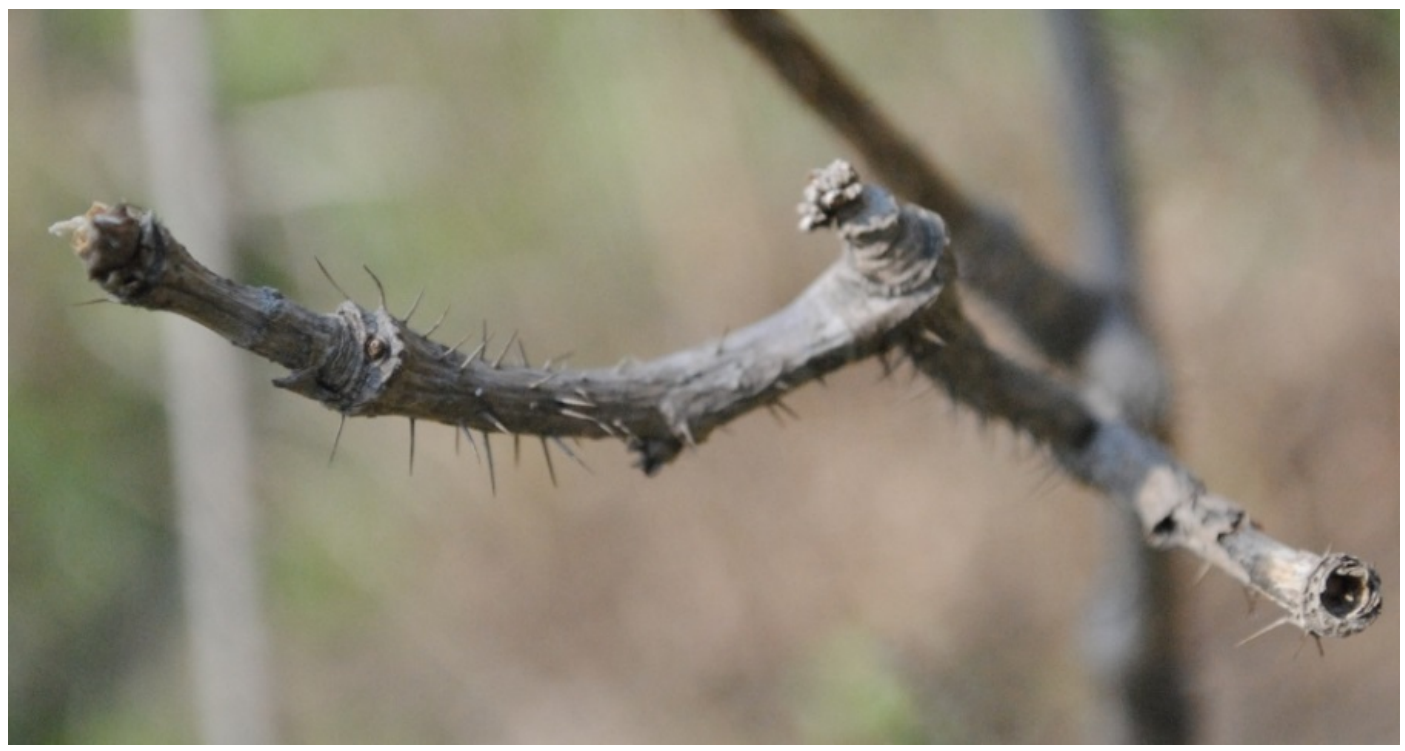

Fig. 4. Branch freezing of Eleutherococcus senticosus

Table 8

Characteristic of state of tree species of Araliaceae Juss. growing on the territory of M.M. Gryshko NBG

\begin{tabular}{lcccccc}
\hline \multicolumn{1}{c}{ Tree specie } & $\begin{array}{c}\text { Quantity, } \\
\text { pcs. }\end{array}$ & $\begin{array}{c}\text { Age, } \\
\text { years }\end{array}$ & $\begin{array}{c}\text { Winter- } \\
\text { resistance, } \\
\text { points }\end{array}$ & $\begin{array}{c}\text { Drought- } \\
\text { resistance, } \\
\text { points }\end{array}$ & $\begin{array}{c}\text { Reproductive } \\
\text { ability, } \\
\text { points }\end{array}$ & $\begin{array}{c}\text { Adaptive index, } \\
\% \text { and points }\end{array}$ \\
\hline Acanthopanax lasiogyne & 1 & 60 & 4 & 4 & 5 & 80, IV \\
Acanthopanax sessiliflorum & 42 & 63 & 4 & 5 & 3 & 60, IV \\
Aralia cordata & 30 & 48 & 3 & 4 & 3 & 36, II \\
Eleutherococcus senticosus & 17 & 59 & 4 & 5 & 4 & 80, III \\
Kalopanax septemlobus & 2 & 64 & 4 & 4 & 4 & 64, III \\
Oplopanax elatus & 2 & 60 & 3 & 4 & 4 & 48, II \\
Panax ginseng & 5 & 64 & 5 & 3 & 3 & 45, II \\
\hline
\end{tabular}


Table 9

Characteristic of state of tree species of Araliaceae Juss. growing on the territory of BG of NULES

\begin{tabular}{lccccccc}
\hline \multicolumn{1}{c}{ Specie } & $\begin{array}{c}\text { Quantity, } \\
\text { pcs. }\end{array}$ & $\begin{array}{c}\text { Age, } \\
\text { years }\end{array}$ & $\begin{array}{c}\text { Height, } \\
\mathrm{m}\end{array}$ & $\begin{array}{c}\text { Winter- } \\
\text { resistance, } \\
\text { points }\end{array}$ & $\begin{array}{c}\text { Drought- } \\
\text { resistance, } \\
\text { points }\end{array}$ & $\begin{array}{c}\text { Reproductive } \\
\text { ability, } \\
\text { points }\end{array}$ & $\begin{array}{c}\text { Adaptive } \\
\text { index, } \\
\text { \% and points }\end{array}$ \\
\hline Acanthopanax sessiliflorum & 1 & 34 & 4,0 & 4 & 5 & 3 & 60, III \\
Aralia mandshurica & 3 & 32 & 3,5 & 4 & 5 & 4 & 80, IV \\
Eleutherococcus senticosus & 1 & 34 & 2.5 & 4 & 5 & 4 & 80, IV \\
Kalopanax septemlobus & 3 & 34 & 18 & 4 & 4 & 4 & 64, III \\
Hedera helix & 2 & 10 & 2 & 4 & 5 & 1 & 20, I \\
\hline
\end{tabular}

On the territory of the O. V. Fomin BG the largest variety of representatives are plants of genus Acanthopanax that characterized by a high level of adaptation (Table 10). As in the previous cases plants of genus Hedera are low-adapted.

Table 10

Characteristic of state of tree species of Araliaceae Juss. growing on the territory of O. V. Fomin BG

\begin{tabular}{lccccccc}
\hline \multicolumn{1}{c}{ Species } & $\begin{array}{c}\text { Quantity, } \\
\text { pcs }\end{array}$ & $\begin{array}{c}\text { Age, } \\
\text { years }\end{array}$ & $\begin{array}{c}\text { Height, } \\
\mathrm{m}\end{array}$ & $\begin{array}{c}\text { Winter- } \\
\text { resistance, } \\
\text { points }\end{array}$ & $\begin{array}{c}\text { Drought- } \\
\text { resistance, } \\
\text { points }\end{array}$ & $\begin{array}{c}\text { Reproductive } \\
\text { ability, } \\
\text { points }\end{array}$ & $\begin{array}{c}\text { Adaptive } \\
\text { index, } \\
\% \text { and points }\end{array}$ \\
\hline Acanthopanax divaricatus & 1 & 44 & 1,5 & 4 & 5 & 4 & 80, IV \\
Acanthopanax sessiliflorum & 1 & 74 & 3 & 4 & 5 & 3 & 60, III \\
Acanthopanax sieboldianus & 1 & 57 & 1,4 & 4 & 5 & 4 & 80, IV \\
Acanthopanax trifoliatus & 2 & 44 & 1,6 & 4 & 4 & 4 & 60, IV \\
Acanthopanax wardii & 1 & 38 & 1,8 & 4 & 4 & 4 & 64, IV \\
Eleutherococcus senticosus & 1 & 46 & 2.4 & 4 & 5 & 4 & 80, IV \\
Hedera helix & 2 & 42 & $\mathrm{x}$ & 4 & 5 & 1 & $20, \mathrm{I}$ \\
Hedera cjlchica & 1 & 42 & $\mathrm{x}$ & 4 & 4 & 2 & $32, \mathrm{II}$ \\
\hline
\end{tabular}

Thus, among the introduced plants only five representatives of genus Acanthopanax - Acanthopanax lasiogyne, Acanthopanax divaricatus, Acanthopanax sieboldianus,
Acanthopanax trifoliatus and Acanthopanax wardii. have high level of adaptation. From the other species only Aralia mandshurica has reached a high level of adaptation (Fig. 5).

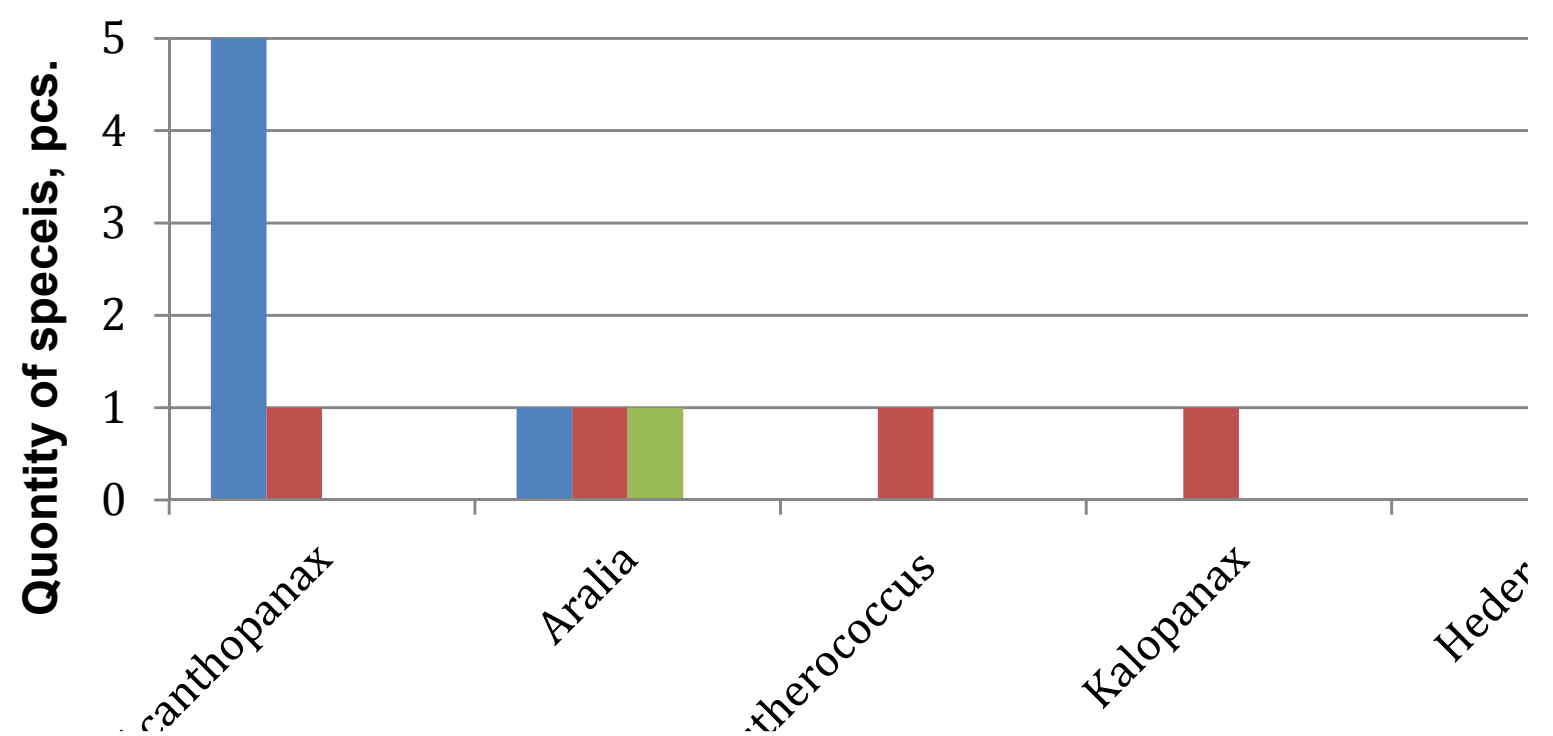

Fig 5. Comparative assessment of the level of adaptation of species of Araliaceae Juss. on the territory of Botanical gardens of Kiev

\section{Conclusions}

According to a comprehensive assessment a large number of studied species were highly evaluated for decorative effect. Thus, introduced species Araliaceae Juss. have good perspective for further usage in ornamental gardening, landscaping of urban areas and private territories. Introduced species of family Araliaceae Juss. in Botanical gardens of Kiev characterized by high-level adaptation to local soil and climatic conditions. The vast majority of them bloom but not all can form seeds. Results of researches showed that they have a high resistance to the effects of adverse factors. All types of this family are promising for introduction into culture and can be widely used in various branches of the national economy. 


\section{References}

Afanasyeva, E. V., Bulah, P. E., Golovko, R. P. (1997). Katalog rasteniy centralnogo botanicheskogo sad im. N. N. Gryshko [Catalog of plants of the Central Botanical Garden of names N. N. Grishko] (in Russion).

Alexeyeva, A. A., Lykholat, Y. V., Khromykh, N. O., Kovalenko, I. M., \& Boroday, E. S. (2016). The impact of pollutants on the antioxidant protection of species of the genus Tilia at different developmental stages. Visnyk of Dnipropetrovsk University. Biology, ecology, 24(1), 188-192.

Davydov, M., Krikorian, A. (2000). Eleutherococcus senticosus (Rupr. \& Maxim.) Maxim. (Araliaceae) as an adaptogen: a closer look. J. of Ethnopharmacology, 72, 345-393.

Endress, P. K. (2002). Morphology and angiosperm systematics in the molecular era. Bot. Rev., 68, 535-548.

Eyde, R. H., Tseng, C. C. (1971). What is the primitive flora structure of Araliaceae? J. Arnold Arbor., 52, 205-239.

Fedorov, A. A. (1982). Zhizn rasteniy. V 6 tomakh [The life of plants. In 6 volumes]. Tsvetkovye rasteniya, 120-133 (in Russian).

Frei, E. R., Ghazoul, J., Matter, P., Heggli, M., Pluess, A. R. (2014). Plant population differentiation and climate change: Responses of grassland species along an elevational gradient. Global Change Biology, 20(2), 439-455.

Fujimaki, Y. (2012). Seeds and fruits eaten by birds. Forest Protection, 328, 27-28.

Heylighen, F. (2007). The Global Superorganism: an evolutionary-cybernetic odel of the emerging network society. Social Evolution and History, 6(1), 58-120.

Kalinichenko, A. A. (1981). Ocenka adaptacii i celesoobraznosti introdukcii drevesnyh rasteniy [Assessment of the adaptation and feasibility of the introduction of woody plants]. Bulletin of the main botanical garden, 108, 3-8 (in Russion).

Karapetyan, N. V., Bukhov, N. G. (1986). Peremennaya fluorestsentsiya khlorofilla kak pokazatel fiziologicheskogo sostoyaniya rasteniy [Variable chlorophyll fluorescence as an indicator of the physiological state of plants]. Fiziologiya rasteniy, 33, 1013-1026 (in Russian).

Kilpatrick, J. (2014). Fathers of Botany. The discovery of Chinese plants by European missionaries. Kew \& Chicago, 254.

Kohno, N. A., Kurdiuk, A. M. (1994). Teoreticheskie osnovy i oput introduktsii drevesnykh rasttenii $\mathrm{v}$ Ukraine [Theoretical foundations and experience of the introduction of woody plants in Ukraine] (in Russion).

Kolesnichenko, O. V., Slyusar, S. I., Yacodchuk, O. M. (2010). Katalog derevnyh roslyn botanichnogo sadu NUBiP
Ukrainy [Catalog of tree-species of botanical garden NULES Ukraine]. NUBiP Ukrainy, Kyiv (in Ukrainian).

Khromykh, N., Lykholat, Y., Shupranova, L., Kabar, A., Didur, O., Lykholat, T., Kulbachko, Y. (2018). Interspecific differences of antioxidant ability of introduced Chaenomeles species with respect to adaptation to the steppe zone conditions. Biosystems Diversity, 26(2), 132-138.

Lykholat, Yu. V. \& Hryhoryuk, I. P. (2005). Vykorystannya dernoutvoryuyuchykh trav dlya diahnostyky rivnya zabrudnennya navkolyshnoho seredovyshcha vazhkymy metalamy [Use of turf herb for the diagnosis of environmental pollution by heavy metals]. Dopovidi Natsionalnoyi akademiyi nauk Ukrayiny, 8, 196-200 (in Ukrainian).

Peregrym, M. M., Bezsmertna, O. O., Erysova, A. V. (2014). Vydy «Chervonoyi knyhy Ukrayiny» u kolektsiynomu fondi dilyanky «Ridkisni ta znykayuchi roslyny pryrodnoyi flory Ukrayiny» Botanichnoho sadu imeni akad. O. V. Fomina [Species from the Red Data Book of Ukraine in «Rare and endangered plants of the natural flora of Ukraine» collection of the O. V. Fomin Botanical Garden]. Chornomorsk. bot. j., 10(1), 120-126.

Prisedsky, Y., Kabar, A., Lykholat, Y., Martynova, N., Shupranova, L. (2017). Activity and isoenzyme composition of peroxidase in Japanese quince vegetative organs under steppe zone conditions. Biologija (Lietuvos mokslu academia), 63(2), 185-192.

Shalimov, I. V. (2008). Kataloh roslyn Zaporizkoho miskoho dytyachoho botanichnoho sadu [Catalog of plants of Zaporizhzhya city children's botanical garden]. Zaporizhzhya (in Ukrainian).

Shang, C. B., Lowry, P. P. II. (2007). Araliaceae. Flora of China, 13, 435-491.

Sokolov, S. Y. (1957). Introdukciya rasteniy i zelenoe stroitelstvo [Introduction of development and green building], 6(5), 34-42 (in Russion).

Umair, M., Altaf, M., Abbasi, A. M. (2017). An ethnobotanical survey of indigenous medicinal plants in Hafizabad district, Punjab-Pakistan. PLoS One, 12(6).

Vorobyev, G. I. (1986). Lesnaya encyklopediya [Forest Encyclopedia]. Soviet encyclopedia, 2 (in Russion).

Zaman, S. U., Ali, K., Khan, W., Ali, M., Jan, T., Nisar, M. (2018). Ethno-botanical and geo-referenced profiling of medicinal plants of Nawagai Valley, District Buner (Pakistan). Biosystems Diversity, 26(1), 46-61.

Zhang, G., Yatskievych, G., Hooper, E. A. (2013). Flora of China. Science Press, 2(3), 234-235. 